\title{
Brain-Derived Neurotrophic Factor Induces Hyperexcitable Reentrant Circuits in the Dentate Gyrus
}

\author{
Ryuta Koyama, ${ }^{1}$ Maki K. Yamada, ${ }^{1}$ Shigeyoshi Fujisawa, ${ }^{1}$ Ritsuko Katoh-Semba, ${ }^{2}$ Norio Matsuki, ${ }^{1}$ and Yuji Ikegaya ${ }^{1}$ \\ ${ }^{1}$ Laboratory of Chemical Pharmacology, Graduate School of Pharmaceutical Sciences, The University of Tokyo, Tokyo 113-0033, Japan, and ${ }^{2}$ Institute for \\ Developmental Research, Aichi Human Service Center, Aichi 480-0392, Japan
}

\begin{abstract}
Aberrant sprouting and synaptic reorganization of the mossy fiber (MF) axons are commonly found in the hippocampus of temporal lobe epilepsy patients and result in the formation of excitatory feedback loops in the dentate gyrus, a putative cellular basis for recurrent epileptic seizures. Using ex vivo hippocampal cultures, we show that prolonged hyperactivity induces MF sprouting and the resultant network reorganizations and that brain-derived neurotrophic factor (BDNF) is necessary and sufficient to evoke these pathogenic plasticities. Hyperexcitation induced an upregulation of BDNF protein expression in the MF pathway, an effect mediated by L-type $\mathrm{Ca}^{2+}$ channels. The neurotrophin receptor tyrosine kinase (Trk)B inhibitor K252a or function-blocking anti-BDNF antibody prevented hyperactivity-induced MF sprouting. Even under blockade of neural activity, local application of BDNF to the hilus, but not other subregions, was capable of initiating MF axonal remodeling, eventually leading to dentate hyperexcitability. Transfecting granule cells with dominant-negative TrkB prevented axonal branching. Thus, excessive activation of L-type $\mathrm{Ca}^{2+}$ channels causes granule cells to express BDNF, and extracellularly released BDNF stimulates TrkB receptors present on the hilar segment of the MFs to induce axonal branching, which may establish hyperexcitable dentate circuits.
\end{abstract}

Key words: hippocampus; granule cell; mossy fiber; epilepsy; sprouting; BDNF

\section{Introduction}

The neural circuit in the dentate gyrus is a highly vulnerable organization. In the brains of patients and animal models of temporal lobe epilepsy, a widely recognized remodeling is the abnormal targeting of hippocampal mossy fibers (MFs), a phenomenon termed MF sprouting. In epileptic hippocampus, the MF axons often bifurcate in the hilar region, and the sprouted collaterals are ectopically guided into the inner molecular layer, where they synapse with the proximal segments of dendrites of granule cells (Cronin and Dudek, 1988; Sutula et al., 1988; de Lanerolle et al., 1989; Babb et al., 1991; Okazaki et al., 1995). Ultrastructural analysis reveals that most of these ectopic synapses are asymmetric (Cavazos et al., 2003) and terminate on dendritic spines (Buckmaster et al., 2002), both of which are typical of excitatory synapses. Thus, granule cells are interconnected, forming their excitatory loop chains in the dentate gyrus.

This plastic remodeling is of particular importance in at least two neurological aspects. First, these abnormal recurrent circuits are functionally active (Molnar and Nadler, 1999; Lynch and Sutula, 2000) and cause hyperexcitation of the dentate gyrus

Received Jan. 15, 2004; revised June 25, 2004; accepted June 28, 2004.

This work was supported by Japan Society for the Promotion of Science. We thank Dr. Rita Balice-Gordon for tTrkB CDNA, Dr. Xiang Yu for technical advice on protocols for transfection, and Dr. Takuya Sakaguchi for his technical support of intracellular staining of single cells. We are also grateful to Ryuji X. Yamada, Jeong-Ah Kim, and Nobuhiro Kawai for daily discussions.

Correspondence should be addressed to Yuji Ikegaya, Laboratory of Chemical Pharmacology, Graduate School of Pharmaceutical Sciences, The University of Tokyo, 7-3-1 Hongo, Bunkyo-ku, Tokyo 113-0033, Japan. E-mail: ikegaya@tk.air.jp.

DOI:10.1523/JNEUROSCI.2045-04.2004

Copyright $\odot 2004$ Society for Neuroscience $\quad$ 0270-6474/04/247215-10\$15.00/0
(Wuarin and Dudek, 1996; Feng et al., 2003), whereby cortical signal is excessively amplified before reaching the hippocampus. These anatomical aberrations, hence, are potential epileptogenic foci, and MF sprouting could be a therapeutic target of temporal lobe epilepsy (Koyama and Ikegaya, 2004). Second, many experimental studies consistently indicate that convulsants with different mechanisms of action, e.g., pilocarpine, kainate, and flurothyl, and kindling stimulation of the limbic system are all capable of inducing MF sprouting, suggesting that the formation of proepileptic recurrent circuits is triggered by neuronal activity. This form of plasticity, i.e., activity-induced hyperexcitability, is "anti-homeostatic" and represents a significant example of neuronal tuning; note that neurons usually undergo homeostatic regulation, depending on the level of past activity (LeMasson et al., 1993; Turrigiano et al., 1994, 1998; Stemmler and Koch, 1999). Therefore, elucidating the characteristic properties of MF sprouting would provide both clinical and neurophysiological insights.

The mechanisms underlying MF sprouting are poorly understood. One candidate of the responsible molecules is brainderived neurotrophic factor (BDNF), a member of the neurotrophin family, which has been implicated as a potent morphoregulator that controls axon branching (Cohen-Cory and Fraser, 1995; Gallo and Letourneau, 1998), dendritic growth (McAllister et al., 1995, 1997), spine density (Shimada et al., 1998; Tyler and Pozzo-Miller, 2001), and activity-dependent refinement of synapses (Cabelli et al., 1995; Horch et al., 1999). In epileptic hippocampus, granule cells display an upregulation of BDNF mRNA (Isackson et al., 1991; Gall, 1993) and protein (Nawa et al., 1995; Elmer et al., 1998; Rudge et al., 1998; Vezzani 
et al., 1999; Katoh-Semba et al., 2001) as well as the BDNF receptor tyrosine kinase (Trk)B mRNA (Bengzon et al., 1993), and phosphorylation of TrkB is also detected in the MF pathway ( $\mathrm{He}$ et al., 2002). However, the causal relationship between BDNF and MF sprouting has been a contentious issue (Binder et al., 2001).

\section{Materials and Methods}

Organotypic cultures of hippocampal slices. Postnatal day 6 Sprague Dawley rats (SLC, Shizuoka, Japan) were deeply anesthetized by hypothermia, and their brains were aseptically removed (Mizuhashi et al., 2001), according to National Institutes of Health guidelines for laboratory animal care and safety. The posterior part of the brain was cut into $300-\mu \mathrm{m}-$ thick transverse slices using a DTK-1500 vibratome (Dosaka, Kyoto, Japan) in aerated, ice-cold Gey's balanced salt solution supplemented with $25 \mathrm{~mm}$ glucose. The entorhino-hippocampi were dissected out under stereomicroscopic controls and cultured using membrane interface techniques (Yamamoto et al., 1989; Stoppini et al., 1991). Briefly, slices were placed on sterile 30-mm-diameter membranes (Millicell-CM; Millipore, Bedford, MA) and transferred into six-well tissue culture trays. Cultures were fed with $1 \mathrm{ml}$ of $50 \%$ minimal essential medium (Invitrogen, Gaithersburg, MD), 25\% horse serum (Cell Culture Lab, Cleveland, $\mathrm{OH}$ ), and $25 \% \mathrm{HBSS}$ and were maintained in a humidified incubator at $37^{\circ} \mathrm{C}$ in $5 \%$ $\mathrm{CO}_{2}$. The medium was changed every $3.5 \mathrm{~d}$.

Dispersed cultures of granule cells. Postnatal day 6 Sprague Dawley rats (SLC) were deeply anesthetized with ether, and the hippocampal formation was dissected out and placed in ice-cold Gey's balanced salt solution, as previously described (Baba et al., 2003). After removal of the subicular complex and the Ammon's horn, the remaining part, i.e., dentate gyrus, was trypsinized and gently triturated, and isolated cells were plated at a density of $5.0 \times 10^{3}$ cells $/ \mathrm{cm}^{2}$ onto $13 \mathrm{~mm}$ culture dishes coated with poly-L-lysine (Sigma, St. Louis, MO) and cultivated in 50\% Neurobasal/ B-27 (Life Technologies, Gaithersburg, MD) and 50\% astrocyteconditioned medium (Mizuhashi et al., 2001) at $37^{\circ} \mathrm{C}$ in a humidified 5\% $\mathrm{CO}_{2}$ and $95 \%$ air atmosphere. The culture medium was changed to the conditioned medium-free Neurobasal/B-27 supplemented with $2 \mu \mathrm{M}$ cytosine-D-arabino-furanoside (Sigma) $24 \mathrm{hr}$ after the plating. To determine to what degree our cultures were contaminated with non-granule, GABAergic cells, they were immunostained with anti-GABA antibody because granule cells are usually GABA-negative (Sloviter and Nilaver, 1987; Buckmaster et al., 2002) although it might not hold true under some extreme conditions (Sloviter et al., 1996). Cultures were sequentially treated with $4 \%$ paraformaldehyde for $30 \mathrm{~min}, 0.1 \%$ Triton X-100 for $30 \mathrm{~min}, 1 \%$ goat serum for $60 \mathrm{~min}$, mixture of primary antibodies to GABA (1:500; mouse, MAB316; Chemicon, Temecula, CA) and MAP-2 (1:1000; rabbit, $\mathrm{AB} 5622$; Chemicon) overnight at $4^{\circ} \mathrm{C}$, and finally with Alexa-488 conjugated anti-mouse IgG (1:400; A-11001; Molecular Probes) and Alexa-594 conjugated anti-rabbit IgG (1:400; A-11012; Molecular Probes) for $2 \mathrm{hr}$ at room temperature. The samples were mounted on coverslips with Vectashield (Vector Laboratories, Burlingame, CA), and images were acquired with an ORCAII cooled CCD (Hamamatsu Photonics, Hamamatsu, Japan), and analyzed with an AQUACOSMOS system (Hamamatsu Photonics). GABA-immunofluorescent intensity in the somata of MAP-2-positive cells was measured and converted into a percentage scale relative to background, as described elsewhere (Yamada et al., 2002). The average intensity of immunofluorescence was $118.5 \pm$ $16.8 \%$ (mean $\pm \mathrm{SD}$ ), but the distribution was bimodal, peaking at $\sim 112 \%$ and $203 \%$. Cells whose GABA immunofluorescence was $>161.4 \%$ (the $99 \%$ confidence limit) were defined as GABA-positive neurons. GABA-positive neurons had the larger cell bodies than GABAnegative neurons. The diameter of GABA-positive cells ranged from 25 to $35 \mu \mathrm{m}$, whereas of $140 \mathrm{GABA}$-negative cells, only one neuron had the cell body larger than $20 \mu \mathrm{m}$ in diameter (three independent experiments). In general, granule cells had the small somata $[10-18 \mu \mathrm{m}$ in vivo (Amaral and Witter, 1995) and $\sim 15 \mu \mathrm{m}$ in culture (Baba et al., 2003)], which indicates that based on the GABA immunoreactivity, we succeeded in discriminating between granule cells and GABAergic interneurons. Under these conditions, only a small portion ( $2.9 \%$ of total) were GABA-positive neurons, and the vast majority (97.1\%) were GABA- negative. These results are consistent with the fact that granule cells make up the overwhelming population of neurons present in the dentate gyrus in vivo (Amaral and Witter., 1995). In the experiments of Figures 7 and 8, cells with somata of $>20 \mu \mathrm{m}$ in diameter were excluded from data. We thus conclude that unexpectedly contaminated non-granule cells, if any, contributed minimally to our results and interpretation.

Neo-Timm staining. After rinsing with PBS, slices were immersed in $0.4 \%$ sodium sulfide solution at $4^{\circ} \mathrm{C}$ for $15 \mathrm{~min}$ and fixed with $10 \%(\mathrm{v} / \mathrm{v})$ formaldehyde for $15 \mathrm{~min}$. After PBS wash, they were dehydrated with 70 and $96 \%$ ethanol each twice for $30 \mathrm{~min}$ and then dried. To perform silver sulfide (Timm) staining, the slices were incubated with citrate-buffered solution containing $20 \%$ Arabic gum, 2.1\% $\mathrm{AgNO}_{3}$, and $0.085 \%$ hydroquinone in a dark room at $26^{\circ} \mathrm{C}$ for $50 \mathrm{~min}$. The slices were washed with distilled water at the end of the reaction. To quantify MF terminals, the images were digitized with a FinePix S1Pro CCD camera (Fuji Photo Film, Tokyo, Japan) equipped with an ECLIPSE TE300 microscope (Nikon, Tokyo, Japan) and a $20 \times$ objective. The pixel intensity values were measured at 8 bit resolution in at least five square areas $(20 \times 20 \mu \mathrm{m}=$ $400 \mu \mathrm{m}^{2}$ ) of dentate hilus, inner molecular layer and subiculum (sub), and then averaged per substratum (Fig. $1 B$ ). These square cursors were separated from each other at intervals of $10-50 \mu \mathrm{m}$ and carefully placed to exclude other subregions. Timm grain intensity was determined by dividing the values of subregions by that of the subiculum (background).

BDNF Immunohistochemistry. Cultured hippocampal slices were fixed with $4 \%$ paraformaldehyde at $4^{\circ} \mathrm{C}$ for $1 \mathrm{~d}$ and permeabilized with $0.1 \%$ Triton X-100 for $30 \mathrm{~min}$. The samples were incubated with $1 \%$ goat serum at room temperature for $60 \mathrm{~min}$, at $4^{\circ} \mathrm{C}$ with $1.6 \mu \mathrm{g} / \mathrm{ml}$ rabbit polyclonal anti-BDNF antibody (Katoh-Semba et al., 2002) overnight, and then with anti-rabbit IgG Alexa-594 (1:400) (Molecular Probes) for $2 \mathrm{hr}$ at room temperature. They were imaged with a Bio-Rad (Richmond, CA) MRC-1024 confocal system with a $10 \times$ objective (Nikon).

Preparation of BDNF-including beads. One milligram of Sephadex G-100 gel beads (Amersham Biosciences, Piscataway, NJ) were immersed in $20 \mu \mathrm{l}$ of $50 \mu \mathrm{g} / \mathrm{ml}$ recombinant human BDNF (Sumitomo Pharmaceuticals, Osaka, Japan) in PBS containing 0.1\% BSA for 15 min. Under stereomicroscopic controls, a bead with $\sim 100 \mu \mathrm{m}$ in diameter was dipped on microdissecting forceps and slowly slid down onto $0 \mathrm{~d}$ in vitro cultures along the tip of another microforceps with extreme care, during which the position of a bead on the slice was manually adjusted under a stereomicroscope. Cultures in which beads were misplaced away from the middle of the subregion of interest were rejected; as a result, $\sim 15 \%$ cultures were excluded. During and after the period of culture, the position of beads was confirmed everyday under stereomicroscopic controls. The bead position was stable after implantation. In a part of the experiments in supplemental Fig. $1 D$ (available at www.jneurosci.org/cgi/content/full/24/33/7215/DC1), bead-included BDNF was re-released by incubation with $20 \mu \mathrm{l}$ of PBS containing $0.1 \%$ BSA at $4^{\circ} \mathrm{C}$ overnight in an Eppendorf tube, and the supernatant was diluted 1:500 in Neurobasal/ B-27 and applied to cultured granule cells to confirm whether BDNF that was once loaded into beads was still biologically active.

ELISA assay for BDNF expression. BDNF was quantified using a Promega ELISA kit (Poulsen et al., 2002). Slices were detached from the membranes and homogenized in $70 \mu \mathrm{l}$ of lysis buffer $(137 \mathrm{~mm} \mathrm{NaCl}, 20$ mм Tris- $\mathrm{HCl}, \mathrm{pH} 8,1 \%$ NP-40, 10\% glycerol, 1 mM PMSF, $10 \mu \mathrm{g} / \mathrm{ml}$ aprotinin, $1 \mu \mathrm{g} / \mathrm{ml}$ leupeptin, and $0.5 \mathrm{~mm}$ sodium vanadate) under sonication on ice. After centrifugation $(1500 \times g$ for $15 \mathrm{~min}), 50 \mu \mathrm{l}$ of supernatant was diluted in $200 \mu \mathrm{l}$ of PBS, divided equally into two Eppendorf tubes, and stored at $-80^{\circ} \mathrm{C}$ until further processing. One of them was subjected to the calculation of BDNF concentration by the ELISA kit, and the other was used for measurements of the total protein content using a Bio-Rad protein assay with bovine serum albumin as standard. The concentration of BDNF was normalized with the total amount of protein and averaged across slices.

Electrophysiology. Patch-clamp recordings were performed as previously described (Tanaka et al., 1997). A slice was transferred to a recording chamber and continuously perfused with oxygenated $\left(95 \% \mathrm{O}_{2}, 5 \%\right.$ $\mathrm{CO}_{2}$ ) artificial CSF (aCSF), consisting of (mM): $124 \mathrm{NaCl}, 25 \mathrm{NaHCO}_{3}, 3$ $\mathrm{KCl}, 1.24 \mathrm{KH}_{2} \mathrm{PO}_{4}, 1.4 \mathrm{MgSO}_{4}, 2.2 \mathrm{CaCl}_{2}$, and 10 glucose. Glass micropipettes (4-7 M $\Omega$ ) were made from glass capillaries with a Narishige (To- 

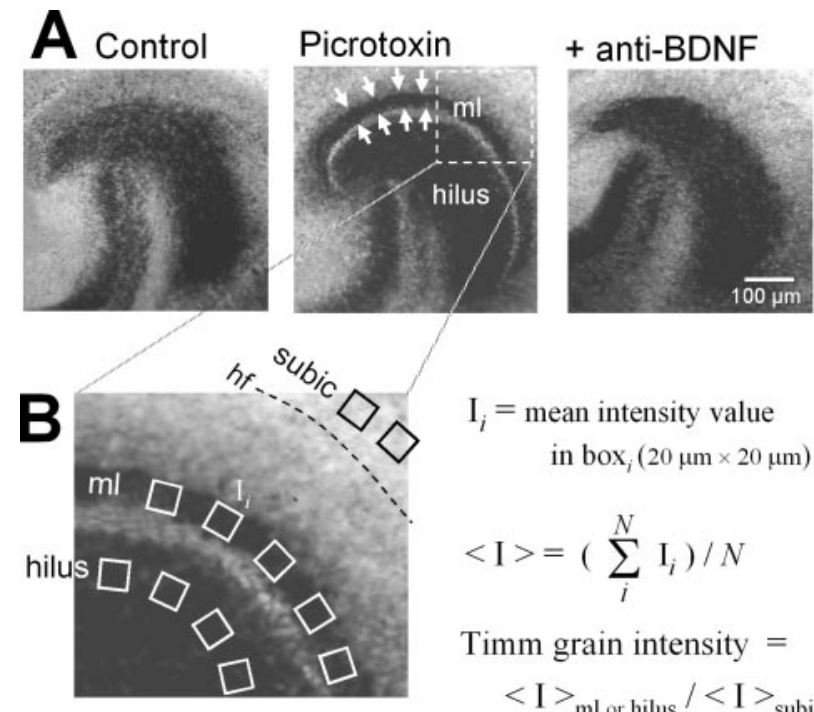

$\mathrm{I}_{i}=$ mean intensity value in $\operatorname{box}_{i}(20 \mu \mathrm{m} \times 20 \mu \mathrm{m})$

$<\mathrm{I}>=\left(\sum_{i}^{N} \mathrm{I}_{i}\right) / N$

Timm grain intensity $=$

$$
<\mathrm{I}>_{\text {ml or hilus }} /<\mathrm{I}>_{\text {subic }}
$$
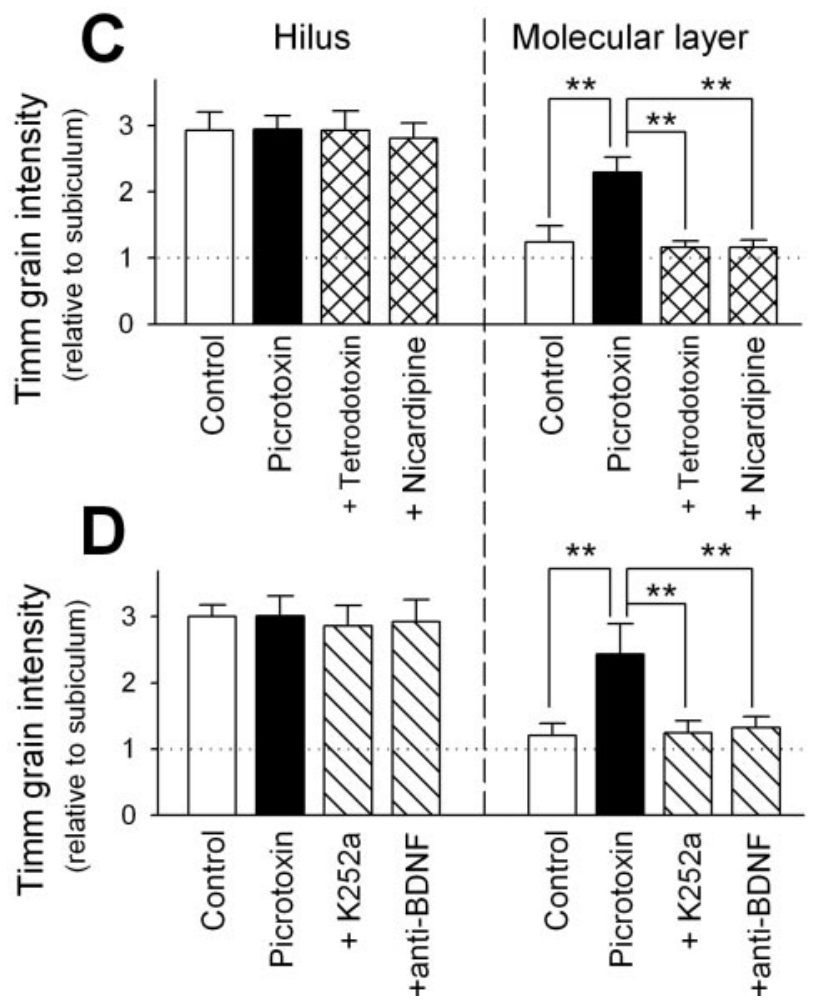

Figure 1. Endogenous BDNF mediates activity-dependent MF reorganization. $A$, Representative Timm staining of hippocampal slice cultures maintained for $10 \mathrm{~d}$ in the absence (left) and presence of $50 \mu \mathrm{m}$ picrotoxin (middle) and a combination of $50 \mu \mathrm{m}$ picrotoxin and $1.6 \mu \mathrm{g} / \mathrm{ml}$ function-blocking anti-BDNF antibody (right). MF heterotopias (arrows) in the inner molecular layer (ml) of picrotoxintreated hippocampus were blocked by cotreatment with anti-BDNF antibody. $B$, Measurement of Timm grain intensity. In an image taken with a $20 \times$ objective, at least five $20 \times 20 \mu$ m cursors were put in each stratum, i.e., hilus, and inner molecular layer (ml), and subicular area (subic) located immediately outside the hippocampal fissure (hf), and the mean signal intensity $(/)$ within the cursors was measured at 8 bit resolution. The / values were averaged for each stratum $\left(<I_{\text {hilus }}>,\left\langle I_{\text {ml }}>\right.\right.$, and $\left\langle I_{\text {subic }}>\right.$ ). Timm grain intensity was defined as $\left\langle I_{\text {hilus }}>\right|<I_{\text {subic }}>$ and $\left\langle I_{\text {ml }}>\right|<I_{\text {subic }}>$.C, Timm grain intensities of the dentate hilus and molecular layer were quantified in control slices and slices that received $10 \mathrm{~d}$ treatment with $50 \mu \mathrm{m}$ picrotoxin in the absence or presence of $1 \mu \mathrm{m}$ tetrodotoxin or $10 \mu \mathrm{m}$ nicardipine. All experiments were repeated with at least four different experiments, producing similar results, with no significant variation from experiment to experiment (Ftest). ${ }^{* *} p<$ 0.01; Tukey's test after ANOVA. Data are means \pm SD of each of $4-16$ slices. D, Same analysis per-

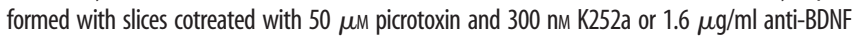
antibody. kyo, Japan) vertical puller. The internal solution consisted of (in $\mathrm{mm}$ ): $136.5 \mathrm{KMeSO}_{4}, 17.5 \mathrm{KCl}, 9 \mathrm{NaCl}, 1 \mathrm{MgCl}_{2}, 10$ HEPES, $0.2 \mathrm{EGTA}$, and 13.4 biocytin, $\mathrm{pH}$ 7.2. Granule cells were held in a current-clamp mode with an Axopatch 200B amplifier (Axon Instruments, Foster City, CA). Single-pulse stimuli were delivered in the presence of $100 \mu \mathrm{M}$ picrotoxin through bipolar tungsten electrodes. The electrodes were positioned on the hilus far apart from the recorded cells to avoid antidromic activation; no contamination of antidromic activation was considered if CNQXAP-5 completely eliminated any responses to the stimulus. Signals were low-pass filtered at $1 \mathrm{kHz}$, digitalized at $10 \mathrm{kHz}$, and analyzed with a pClamp 8.0 software (Axon Instruments).

Intracellular labeling and camera lucida reconstructions of recorded neurons. After whole-cell recordings, slices were washed three times with PBS at room temperature for $5 \mathrm{~min}$ and fixed with $4 \%$ paraformaldehyde at $4^{\circ} \mathrm{C}$ for $60 \mathrm{~min}$. After being washed three times with PBS for each $15 \mathrm{~min}$, they were permeabilized with $0.1 \%$ Triton X-100 for 20 min, washed again with PBS for $10 \mathrm{~min}$, and then incubated with $10 \mu \mathrm{g} / \mathrm{ml}$ Texas Red-X-conjugated streptavidin (Molecular Probes) in a dark room at room temperature for $3 \mathrm{hr}$. Incubation was terminated by PBS wash for each 10 min. Streptavidin-labeled granule cells were observed with a Bio-Rad MRC-1024 confocal system and reconstructed with the camera lucida method.

Morphometric analysis of axonal protrusions. Cultures were fixed with $4 \%$ paraformaldehyde for $30 \mathrm{~min}$ and treated with $0.1 \%$ Triton X-100 for $30 \mathrm{~min}$ and $1 \%$ goat serum for $60 \mathrm{~min}$. They were treated overnight at $4^{\circ} \mathrm{C}$ with primary antibodies against anti-tau-1 (1:2000; mouse monoclonal, MAB3420; Chemicon) and anti-MAP-2 (1:1000; rabbit, AB5622; Chemicon) and then with secondary antibodies anti-mouse IgG Alexa488 (1:400; A-11001; Molecular Probes) and anti-rabbit IgG Alexa-350 (1:400; A-11046; Molecular Probes) in the presence of rhodamine phalloidin (1:40; R-415; Molecular Probes) for $2 \mathrm{hr}$ at room temperature. The samples were mounted on coverslips with Vectashield and imaged with an ORCAII cooled CCD, and analyzed with an AQUACOSMOS system). We defined the longest, tau-1-positive, MAP-2-negative neurite as an axon and counted phalloidin-positive, growth cone-like structures budding out of the axon as protrusions only if they visibly conveyed both lamellipodia and filopodia. For each axon, the density of protrusions was calculated by dividing the number of protrusions by the axon length.

DNA transfection. The cDNA coding truncated TrkB, which lacks the kinase domain (mouse trkB.T1, 1-1428), was subcloned into a pIREShrGFP expression vector (Stratagene, La Jolla, CA). In experiments with a negative control for gene expression, $\beta$-galactosidase (lacZ) was also subcloned into the same vector. Cultured granule cells were transfected with the DNA purified with QIA filter Plasmid Midi kits (Qiagen, Hilden, Germany), using the calcium phosphate precipitation method ( $1 \mu \mathrm{g}$ of DNA per 28,500 cells in a $1.9 \mathrm{~cm}^{2}$ well) (Ohba et al., 2004). The vector pIRES-hrGFP has a cytomegalovirus promoter upstream and IRES (internal ribosomal entry site)-hrGFP (humanized Rotylenchulus reniformis green fluorescence protein) that works as transfection reporter downstream.

Immunocytochemical analysis of nuclear c-Fos expression. To confirm the validity of our experimental tools, i.e., function-blocking anti-BDNF body, dominant-negative TrkB and BDNF included in beads, their effect of BDNF-induced c-Fos expression was tested in granule cell cultures (Ohba et al., 2004). c-Fos immunostaining was performed by using a primary antibody against anti-c-fos (1:1000; mouse, SC-8047; Santa Cruz Biotechnology, Santa Cruz, CA) and then with a secondary antimouse IgG antibody conjugated with Alexa-594 (1:400; A-11032; Molecular Probes) in the presence of Hoechst (1:100,000; H-1399; Molecular Probes). c-Fos immunofluorescence within Hoechst-positive areas (nuclei) was analyzed as an index for BDNF-induced cellular response. The effect of BDNF reached a peak $1 \mathrm{hr}$ after application (supplemental Fig. $1 \mathrm{~B}$, available at www.jneurosci.org/cgi/content/full/24/33/7215/DC1) and rendered the maximal at concentrations of $10 \mathrm{ng} / \mathrm{ml}$ and more (supplemental Fig. $1 C$, available at www.jneurosci.org/cgi/content/full/24/33/7215/DC1). Thus, $1 \mathrm{hr}$ application of $10 \mathrm{ng} / \mathrm{ml}$ BDNF was used for this assay. BDNFinduced expression was blocked by anti-BDNF body as well as K252a, a broad-spectrum Trk inhibitor (supplemental Fig. $1 A, D$, available at www. jneurosci.org/cgi/content/full/24/33/7215/DC1). The blocking effect was 
also attained by overexpression of a dominant-negative form of TrkB (supplemental Fig. 2, available at www.jneurosci.org/cgi/content/full/24/33/ $7215 / \mathrm{DC} 1)$. In addition, BDNF that was exuded from beads was still capable of inducing c-Fos expression. We thus concluded that functionblocking anti-BDNF antibody, dominant-negative TrkB, and BDNF included in beads were biologically active in our experimental system.

\section{Results}

\section{Hyperactivity induces MF sprouting ex vivo}

Entorhino-hippocampal slices prepared from postnatal rat pups were organotypically cultivated in the presence of picrotoxin, a $\mathrm{GABA}_{\mathrm{A}}$ receptor channel blocker that is reported to efficiently evoke prolonged epileptiform discharges without apparent desensitization or adaptation for up to $50 \mathrm{~d}$ in vitro (Ikegaya et al., 1998; Ikegaya, 1999). After $10 \mathrm{~d}$ in culture, slices were stained with the Timm method, a histochemical technique to assess the spatial distribution of MF terminals because of their high $\mathrm{Zn}^{2+}$ content (Danscher and Zimmer, 1978; Ueno et al., 2002). Because Timm signal is specific for synaptic terminals but does not detect MF axonal segments that form no synapses (Danscher and Zimmer, 1978), Timm grain intensity in the hilus is unaffected by mossy fiber sprouting and hence can serve as a negative internal control. In intact cultures, Timm signal was spatially limited in the dentate hilus and stratum lucidum. However, when cultured in the presence of picrotoxin, the inner molecular layer also became Timm-positive, and the staining pattern resembles a histological feature in temporal lobe epilepsy, indicative of MF sprouting (Fig. $1 A, B)$. This ectopic Timm signal was completely abolished by coapplication of tetrodotoxin, a voltage-sensitive $\mathrm{Na}^{+}$channel blocker (Fig. 1C). Thus, MF sprouting is activity-dependent.

We next sought to determine whether or not picrotoxin induces an increase in expression of BDNF, another characteristic of epileptic hippocampus (Nawa et al., 1995; Elmer et al., 1998; Rudge et al., 1998; Vezzani et al., 1999). As expected, ELISA assay revealed that picrotoxin treatment significantly elevated the level of BDNF protein expression in the homogenates of slices, and the increase was blocked by tetrodotoxin (Fig. $2 A, B$ ). Upregulation of BDNF was observed at $24 \mathrm{hr}$ of exposure, reached a peak after $48 \mathrm{hr}$, and thereafter declined to a steady-state level that was still approximately fivefold higher than control (Fig. 2A). Immunohistochemical analyses revealed that BDNF was induced in a lamina-specific manner, i.e., selectively in the stratum lucidum, dentate hilus, and molecular layer (Fig. 2C). These substrata correspond with the MF pathway. We therefore conclude that epilepsy-relevant MF sprouting can be reliably replicated in our ex vivo culture system.

\section{BDNF-TrkB signaling mediates MF sprouting}

An increase in intracellular $\mathrm{Ca}^{2+}$ levels (Ghosh et al., 1994; Sano et al., 1996) through $\mathrm{Ca}^{2+}$ influx via L-type $\mathrm{Ca}^{2+}$ channels or NMDA receptors (Shieh et al., 1998; Tao et al., 1998; Tabuchi et al., 2000) is known to induce BDNF expression. Consistent with this, nicardipine, an L-type $\mathrm{Ca}^{2+}$ channel blocker, inhibited hyperactivity-induced increase in BDNF (Fig. 2 B). Interestingly, nicardipine also abolished picrotoxin-induced Timm signal in the molecular layer (Fig. 1C). These effects of nicardipine imply that the BDNF upregulation mediates MF sprouting. To confirm this, we applied picrotoxin in the presence of K252a, a broadspectrum Trk inhibitor. No MF sprouting now occurred (Fig. $1 D)$. Similar results were obtained by cotreatment with functionblocking anti-BDNF antibody (Fig. 1 $A, D$ ), suggesting that extracellularly released BDNF contributes to MF sprouting by acting on TrkB receptors. The validity of the blocking effect of this spe-
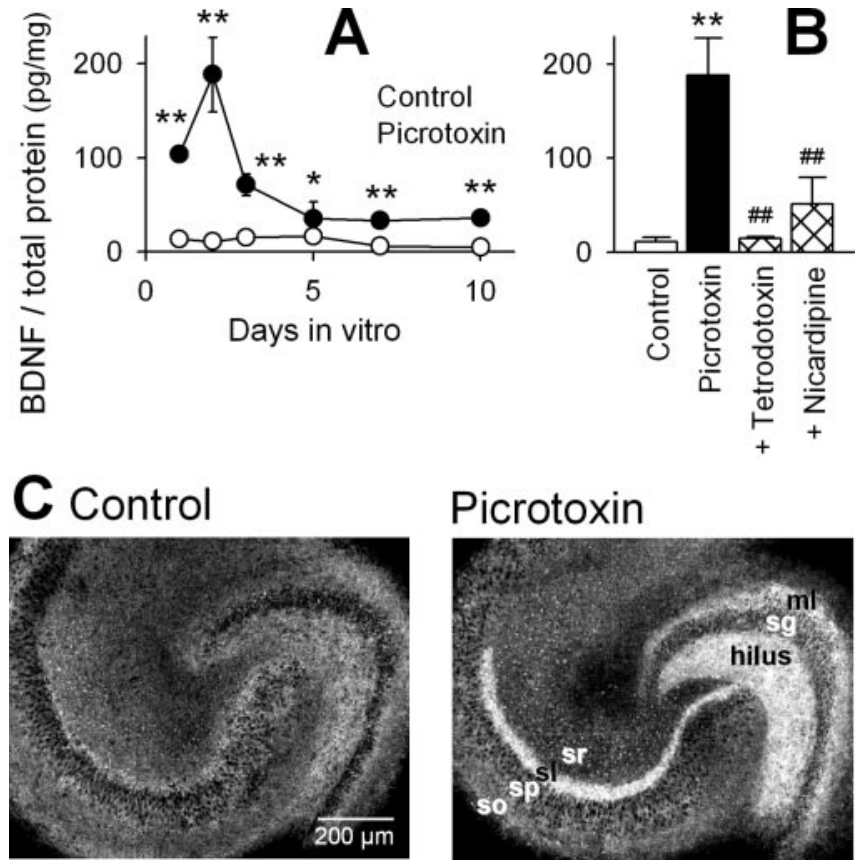

Figure 2. Lamina-specific induction of BDNF protein in hyperexcited hippocampus. A, ELISAbased quantification of changes in BDNF expression in hippocampal slices cultivated in the absence and presence of $50 \mu \mathrm{m}$ picrotoxin. B, BDNF was quantified in slices exposed to $50 \mu \mathrm{m}$ picrotoxin for $2 \mathrm{~d}$ in the absence and presence of $1 \mu \mathrm{m}$ tetrodotoxin and $10 \mu \mathrm{m}$ nicardipine. ${ }^{*} p<0.05 ;{ }^{* *} p<0.01$ versus control; $; \# p 0.01$ versus picrotoxin; Tukey's test after ANOVA. Data are means \pm SD of $4-8$ slices. C, Immunohistochemical staining for BDNF in control and picrotoxin-treated (50 $\mu \mathrm{m}$ for $10 \mathrm{~d}$ ) slices. BDNF expression was selectively induced in the stratum lucidum (sl), hilus and molecular layer ( $\mathrm{ml}$ ), but not the stratum oriens (so), pyramidale $(\mathrm{sp})$, radiatum (sr), or granulosum (sg).

cific neutralizing antibody to BDNF was confirmed in a previous paper (Katoh-Semba et al., 2002) as well as supplemental Figure 1 (available at www.jneurosci.org/cgi/content/full/24/33/7215/ DC1) (for details, see Materials and Methods).

We investigated the time course of changes in the pattern of Timm staining after exposure to picrotoxin. MF sprouting began to occur $5 \mathrm{~d}$ after application of picrotoxin, lagging behind peak levels of BDNF by $3 \mathrm{~d}$ (Fig. 3).

To further clarify the involvement of BDNF, BDNFcontaining dextran-gel beads $(\sim 100 \mu \mathrm{m}$ diameter $)$ were implanted on various subregions of hippocampal slices, i.e., the hilus, molecular layer, stratum lucidum, and stratum radiatum (one bead per slice). We confirmed that BDNF loaded in beads was still biologically active (supplemental Fig. $1 D$, available at www.jneurosci.org/cgi/content/full/24/33/7215/DC1; for details, see Materials and Methods). Timm signal was evident in the molecular layer only when BDNF-including beads were placed on the hilus, but not the other subregions (Fig. 4A,B). Hilar beadinduced MF sprouting was blocked by K252a or anti-BDNF antibody (Fig. 4A,C). Control beads containing buffer failed to produce any changes in the Timm appearance (Fig. $4 A, C$ ). Therefore, among the subareas that undergo BDNF upregulation, the hilar region solely is responsible for MF heterotopias. Interestingly, BDNF was unable to cause MF sprouting when directly added to the culture medium even at a high concentration of $100 \mathrm{ng} / \mathrm{ml}$ (Fig. 4B), which implies a requirement of region-specific, local activation of BDNF signaling. BDNFinduced MF sprouting was insensitive to tetrodotoxin, nicardipine, the non-NMDA receptor antagonist CNQX, or the NMDA receptor antagonist AP-5 (Fig. 4C). Thus, neither neuronal activ- 


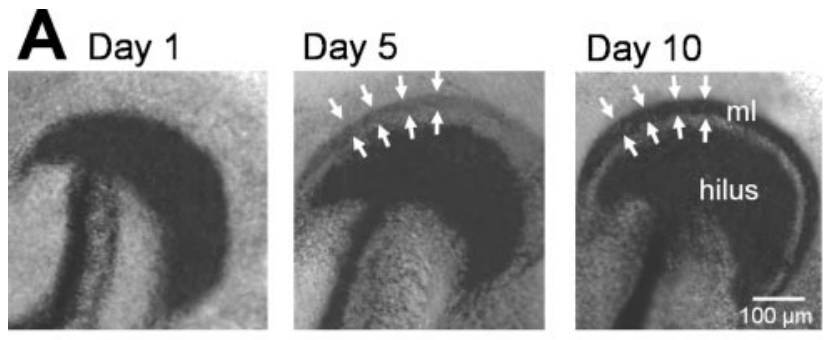

B

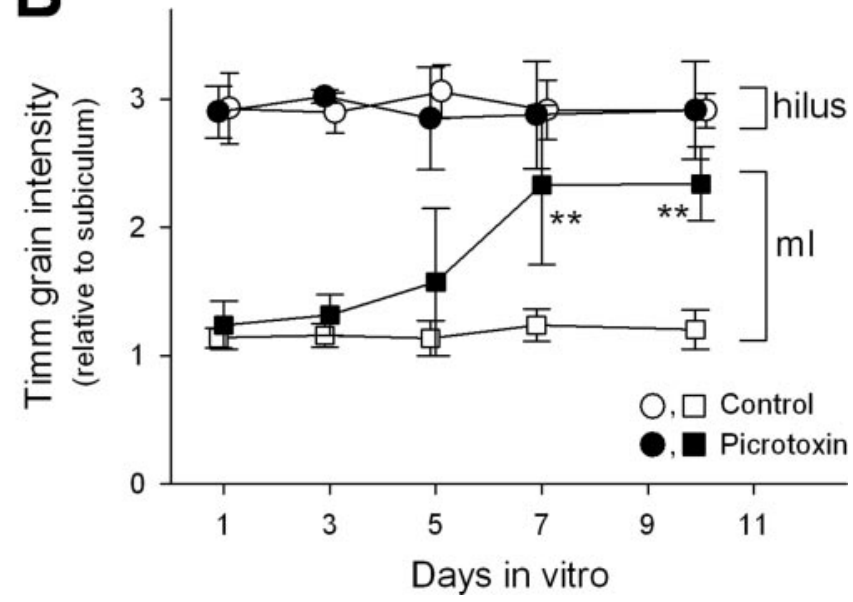

Figure 3. Late onset of hyperexcitation-induced mossy fiber sprouting. $A$, Representative Timm images around the crest of dentate gyrus including the dentate hilus (hilus), stratum granulosum and inner molecular layer $(\mathrm{ml})$ of slices cultured in the presence of $50 \mu \mathrm{m}$ picrotoxin for 1, 5, and $10 \mathrm{~d}$. Arrows indicate sprouted MFs. B, Time course of occurrence of mossy fiber sprouting after picrotoxin application. Timm grain intensities of the dentate hilus (circles) and molecular layer (squares) were quantified in the absence (open symbols) or presence (closed symbols) of $50 \mu \mathrm{m}$ picrotoxin at 1-10 d in vitro. Hyperexcitation did not induce mossy fiber sprouting until at least $5 \mathrm{~d}$ after application. ${ }^{* *} p<0.01$ versus control; Tukey's test after ANOVA. Data are means \pm SD of each of 5-8 slices obtained from four independent experiments.

ity nor L-type $\mathrm{Ca}^{2+}$ channel activity are indispensable for the BDNF effect. These data suggest that hyperactivity-induced MF sprouting is mediated (and completely accounted for) by $\mathrm{Ca}^{2+}$. dependent induction of BDNF expression in the hilus.

To determine how long treatment with BDNF is required to induce MF sprouting, a BDNF-including bead was put on the dentate hilus at day 0 in vitro, and K252a was applied at day 0 -9 in vitro to block the action of BDNF. K252a was continuously present in the culture medium until day 10 when sprouting was assessed by Timm staining. We found that $1 \mathrm{~d}$ stimulation of TrkB is enough to induce MF sprouting (Fig. 5). BDNF is hence likely to contribute to an early stage of MF sprouting, possibly serving as a branch-inducing factor (see below).

Using whole-cell patch clamp recordings, we examined the physiological consequences of picrotoxin-induced and BDNFinduced MF sprouting. Granule cells were held in current clamp, and a portion of the hilus was extracellularly microstimulated, the position and intensity of stimulation being carefully selected to elicit no antidromic activation in the recorded neurons (Fig. $6 \mathrm{~A}$ ). Cells were also filled with neurobiocytin for post hoc morphological identification. In all seven neurons tested in picrotoxin-treated slices and six neurons in BDNF beadembedded slices, the MF axons were found to branch out in the hilus, and at least one of the collaterals extended into the stratum granulosum and inner molecular layer (Fig. 6C,E). Such an ec-
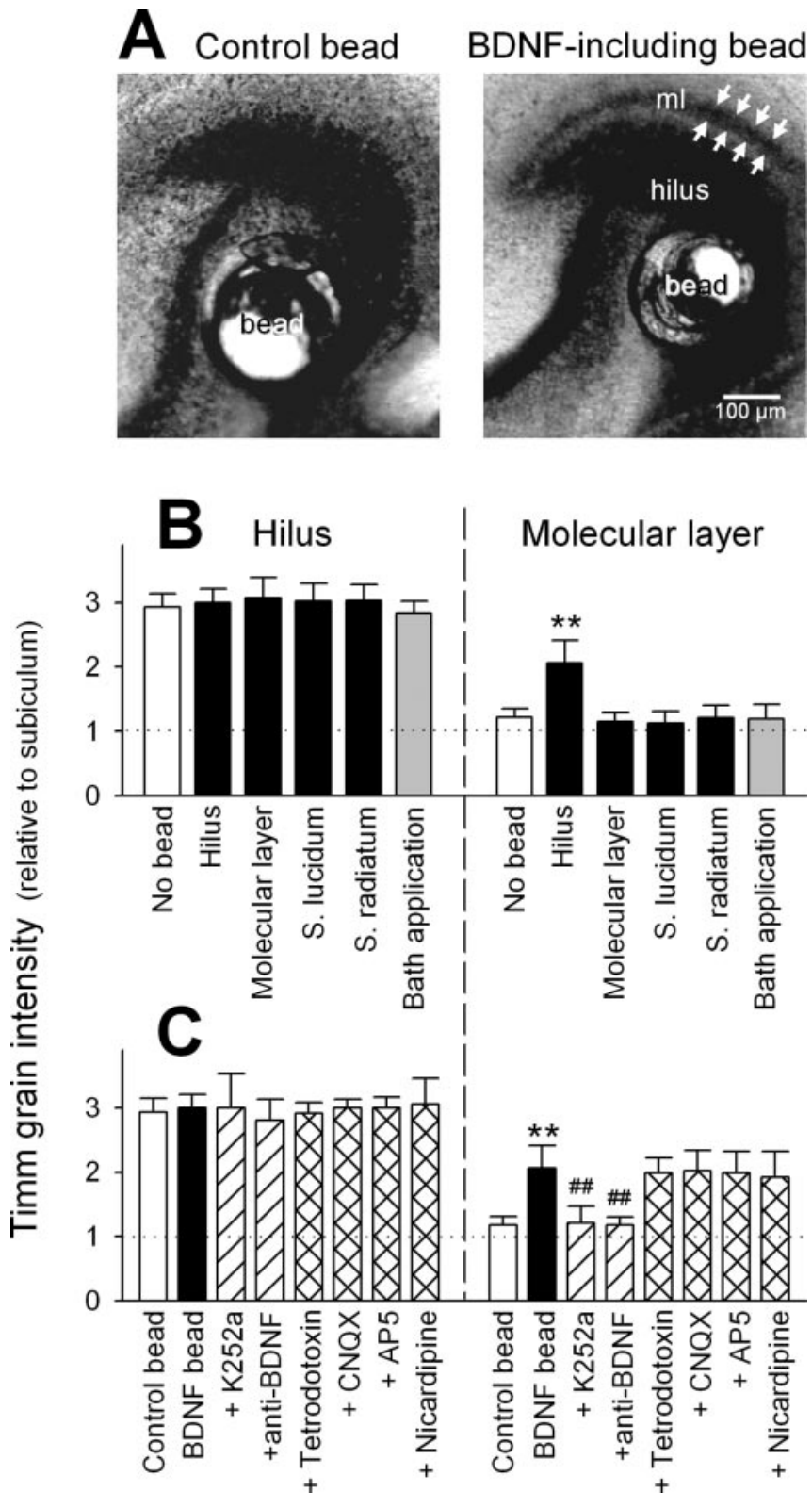

Figure 4. Exogenous application of BDNF to the hilus, but not other subregions, induces activity-independent MF sprouting. $A$, Timm images of hippocampal slices with their hilar regions carrying PBS-including (left) and BDNF-including beads (right) for $10 \mathrm{~d}$. Ectopic MF terminals (arrows) were found in the molecular layer (ml) of the BDNF bead-bearing slice. B, Timm grain intensities of the dentate hilus and molecular layer were quantified in slices in which BDNF-containing beads were put on their hilus, molecular layer, stratum lucidum, or stratum radiatum for $10 \mathrm{~d}$. In the data of "bath application", $100 \mathrm{ng} / \mathrm{ml}$ BDNF was directly added to culture medium without beads, and the medium was replaced with fresh ones containing 100 $\mathrm{ng} / \mathrm{ml}$ BDNF every $24 \mathrm{hr}$ until day 10. C, Same paradigm of analysis as shown in B, from beadcarrying slices treated for $10 \mathrm{~d}$ with $300 \mathrm{~nm} \mathrm{K252a}, 1.6 \mu \mathrm{g} / \mathrm{ml}$ anti-BDNF antibody, $10 \mu \mathrm{m}$ CNQX, $100 \mu \mathrm{m}$ AP-5, $1 \mu \mathrm{m}$ tetrodotoxin, or $10 \mu \mathrm{m}$ nicardipine. ${ }^{* *} p<0.01$ versus control or no bead; $\# p<0.01$ versus BDNF bead; Tukey's test after ANOVA. Data are means \pm SD of each of $4-12$ slices obtained from four independent experiments.

topic MF pathway was never observed in intact or control beadimplanted slices (Fig. 6B,D). In picrotoxin-treated and BDNFtreated slices, hilar microstimulation elicited a paroxysmal depolarizing shift (PDS) (Steriade, 2003) of granule cells with burst firings (Fig. 6C,E). PDS is one of the best cellular markers of an epileptic event, corresponding to the interictal spike of the EEG. It is manifested by a sustained movement of the neuronal 


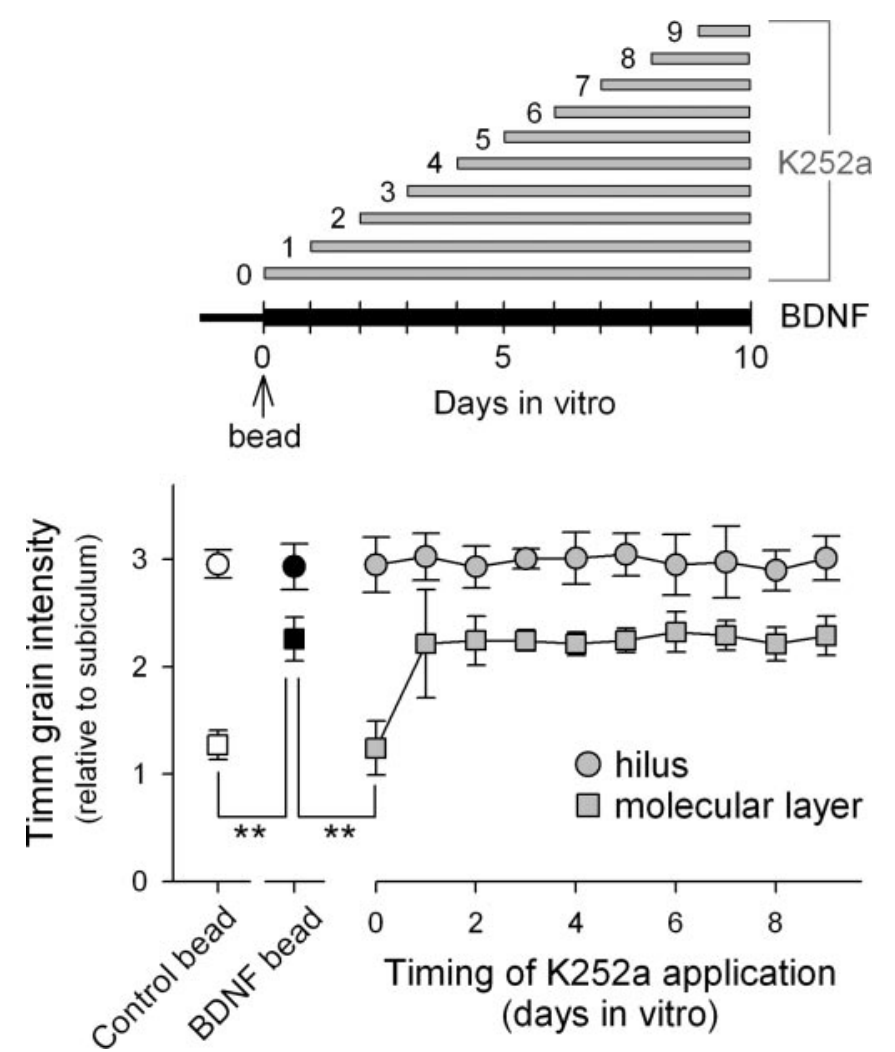

Figure 5. Transient exposure to BDNF is enough to induce MF sprouting. $A$, Experimental procedure. A control or BDNF-containing bead was put on the dentate hilus at day 0 in vitro. To block the action of BDNF, K252a was applied at day $0-9$ in vitro and continuously present in the culture medium until day 10 when sprouting was assessed by Timm staining. B, Timm grain intensities of the dentate hilus (circles) and molecular layer (squares) were quantified in control slices (open symbols) and slices that received 10-day treatment with BDNF-including beads and were cultured in the absence (closed symbols) or presence of $300 \mathrm{~nm} \mathrm{K252a}$ (gray symbols). Exposure to BDNF for as little as $1 \mathrm{~d}$ was capable of inducing MF sprouting. ${ }^{* *} p<0.01$; Tukey's test after ANOVA. Data are means \pm SD of each $5-11$ slices obtained from four independent experiments.

resting potential above threshold for a normal action potential, accompanied by bursts of action potentials (Ayala et al., 1973; Dichter and Ayala, 1987). PDS occurred with a latency of $5.78 \pm$ $2.53 \mathrm{msec}$ after stimulation and lasted $0.74 \pm 0.31 \mathrm{sec}$ (mean \pm $\mathrm{SD}$ of six neurons). Because our conditions of stimulation did not evoke antidromic activation of recorded granule cells, PDS was synaptically triggered by other granule cells in the vicinity of the recorded cells. Indeed, this ictal activity was blocked by a combination of $10 \mu \mathrm{M}$ CNQX and $100 \mu \mathrm{M}$ AP-5 (data not shown) and did not occur in control slices (Fig. $6 B, D$ ), indicating that MF sprouting resulted in synaptic interconnections among granule cells, i.e., feedback excitatory circuits. Both hyperactivityinduced and BDNF-induced MF sprouting, therefore, can reorganize the dentate networks in a similar way, eventually leading to hyperexcitability.

BDNF acts directly on granule cells to induce MF sprouting Although the present study has suggested that BDNF released in the hilus induces MF sprouting, the target cells on which BDNF acts remain unclear because organotypic cultures contain various types of cells. We therefore isolated granule cells from postnatal day 6 rat dentate gyrus and dispersed them on culture plates. After $5 \mathrm{~d}$, their MF axons, which were identifiable with immunoreactivity for tau-1 and easily distinguishable from MAP-2-
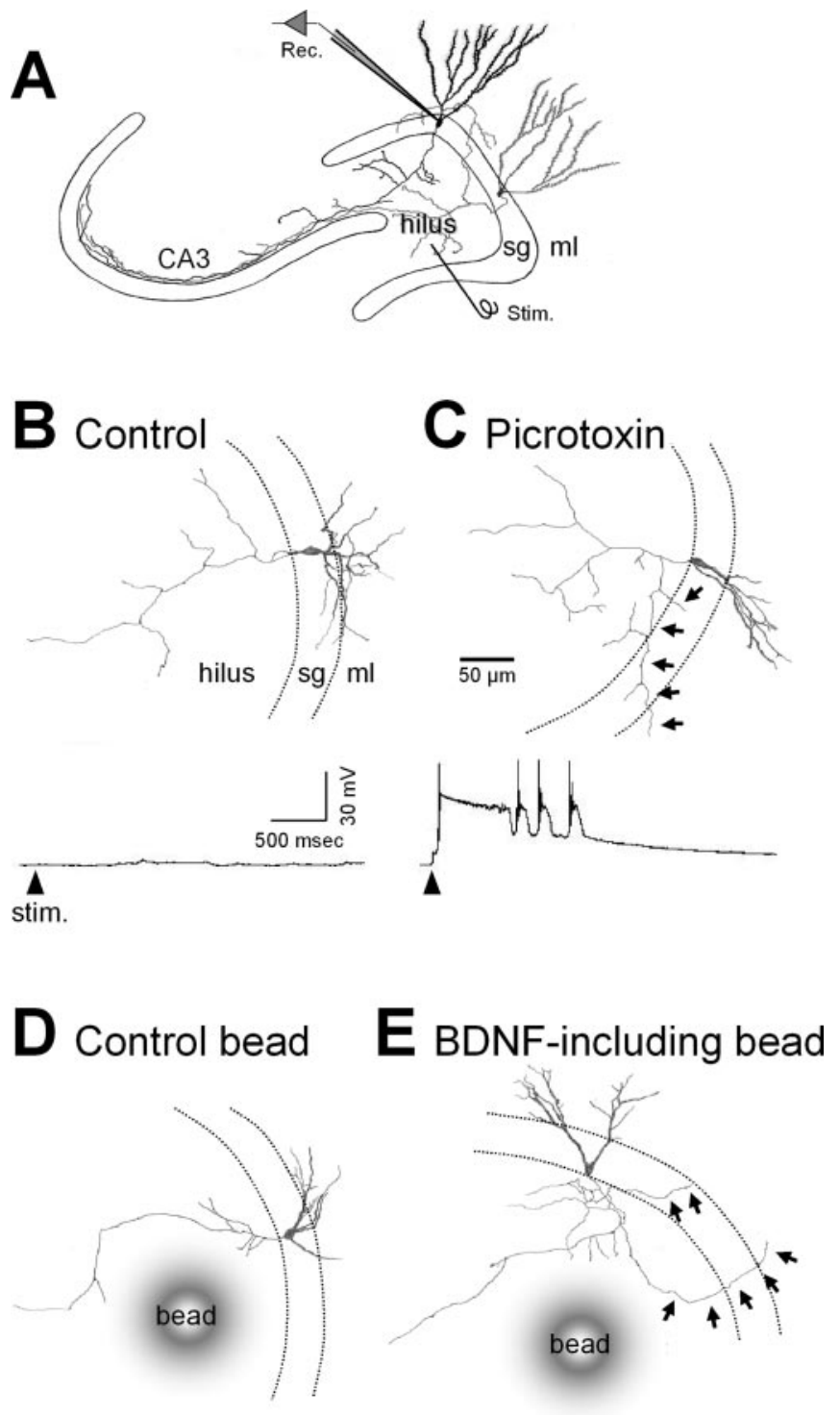

\section{$\widetilde{A}$}

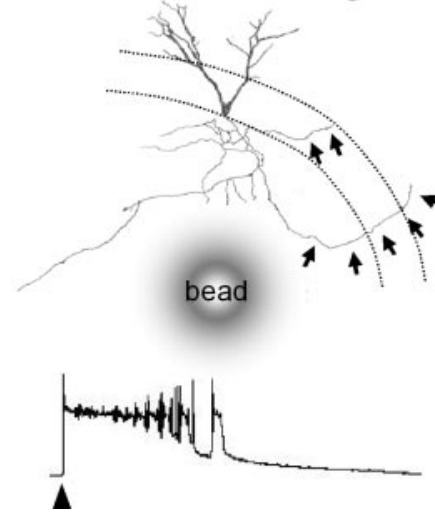

Figure 6. Granule cells display prolonged epileptiform activity after chronic BDNF treatment. $A$, Schematic draw of positions of stimulating (Stim.) and patch-clamp recording (Rec.) electrodes. Response of a granule cell present in the stratum granulosum ( $\mathrm{sg}$ ) to a single-pulse stimulus of the dentate hilus was monitored with whole-cell current clamp recording. Recording was performed with a granule cell located at least $350 \mu \mathrm{m}$ apart from a stimulating electrode, and the intensity of filed stimulation were carefully adjusted to generate no antidromic activation in the recorded neurons, which was checked by application of tetrodotoxin at the end of experiments. $B-E$, Each trace on the bottom indicates a typical intracellular response to local stimulation of the hilus, recorded from the corresponding neurobiotin-filled, camera lucidareconstructed granule cell (top) in a control (B) or $50 \mu \mathrm{m}$ picrotoxin-treated slice $(C)$, or a slice carrying a control $(D)$ or BDNF-including $(E)$ bead in the hilus. Hilar stimulation (arrowheads) caused paroxysmal activation of the granule cells in picrotoxin- or BDNF-treated slices, in which MF collaterals often invaded the stratum granulosum ( $\mathrm{sg}$ ) and even the molecular layer ( $\mathrm{ml}$ ), as indicated by the arrows.

positive dendrites (Fig. 7A), were frequently accompanied by actin-rich protrusions; the average density of the protrusions was $23.2 \pm 2.4 \mathrm{~mm}^{-1}$ along axon length (mean \pm SEM of 248 axonal segments) (Fig. 7A, arrows).

When granule cells were treated with BDNF for $24 \mathrm{hr}$, the 

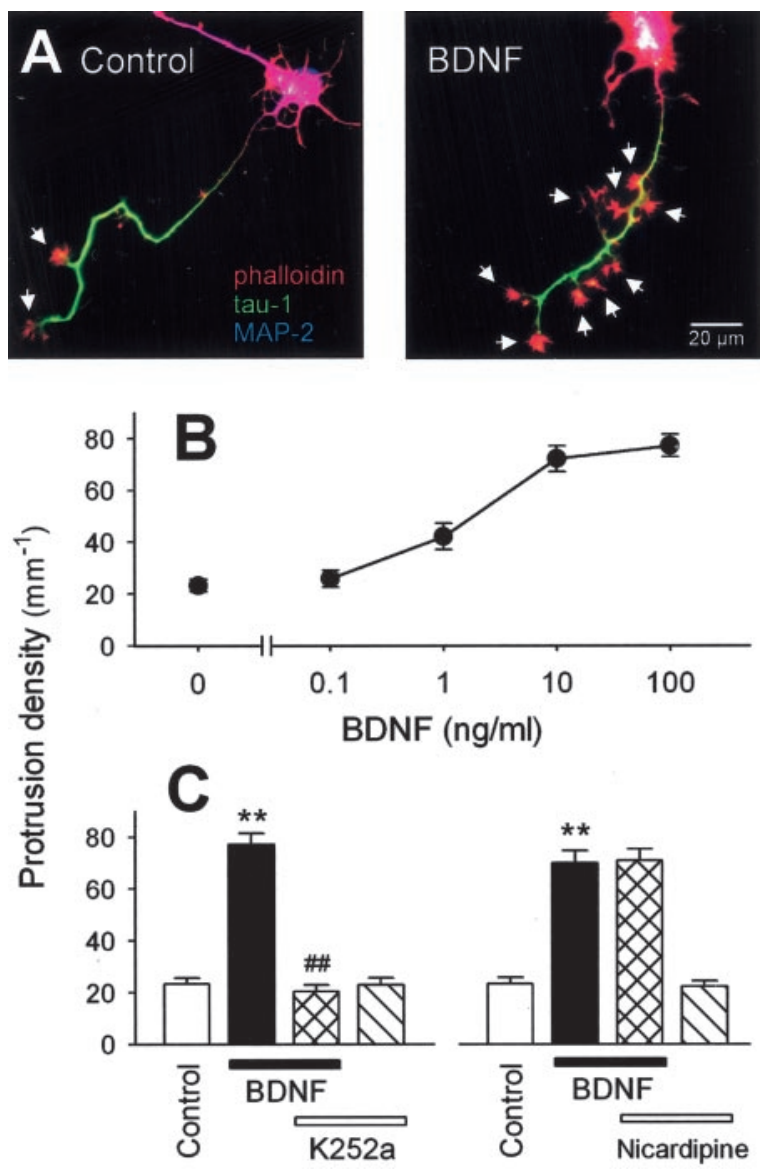

Figure 7. BDNF promotes the formation of axonal protrusions of granule cells. A, Confocal images of isolated granule cells stained with rhodamine phalloidin (red), anti-tau-1 (green), and anti-MAP-2 (blue) after $24 \mathrm{hr}$ treatment with (right) or without (left) $100 \mathrm{ng} / \mathrm{ml} \mathrm{BDNF}$. In the following analyses, we regarded the longest, tau-1-positive, MAP-2-nevative neurite as an axon and measured the density of phalloidin-positive protrusions (arrows) along the axon length. $B$, Dose-dependent effect of BDNF on the density of axonal protrusions. BDNF was added in the media at day 4 in culture and continuously present for $24 \mathrm{hr}$. Observation was performed at day 5. C, Axonal protrusions were counted in cultures treated for $24 \mathrm{hr}$ with or without $10-100 \mathrm{ng} / \mathrm{mlBDNF}$ in the absence or presence of $300 \mathrm{~nm}$ K252a and $10 \mu \mathrm{m}$ nicardipine. ${ }^{* *} p<$ 0.01 versus control; ${ }^{\# \#} p<0.01$ versus BDNF; Tukey's test after ANOVA. Data are means \pm SEM of 162-263 axonal segments in eight different series of experiments.

number of axonal protrusions increased up to fourfold in a concentration-dependent manner (Fig. 7B), an effect sensitive to K252a, but not to nicardipine (Fig. 7C). Therefore, BDNF probably causes the MFs to sprout out via TrkB receptor activation, independent of $\mathrm{Ca}^{2+}$ influx via L-type $\mathrm{Ca}^{2+}$ channels.

We next transfected cultured granule cells with truncated TrkB receptors (TrkB.T1), which lacks intracellular kinase domain, and visualized the transfected neurons with cotransfected green fluorescent protein (GFP) (Fig. 8A). At first, we confirmed that this isoform of TrkB can actually serve as a dominantnegative form of TrkB receptor ( $\mathrm{dnTrkB}$ ) against BDNF signaling, that is, it efficiently blocked $10 \mathrm{ng} / \mathrm{ml}$ BDNF-induced c-Fos expression in our experimental system (supplemental Fig. 2, available at www.jneurosci.org/cgi/content/full/24/33/7215/ DC1; also see Materials and Methods). dnTrkB-transfected granule cells did not undergo the morphological changes in response to BDNF, whereas both untransfected neurons in the same cultures and control lac $Z$ vector-transfected cells responded to BDNF by increasing their axon protrusions to a similar extent
(Fig. $8 A, B$ ). These results indicate that granule cells are the direct target of BDNF action.

\section{Discussion}

Synaptic remodeling is a fundamental process in the development, maintenance, and pathology of the brain. BDNF has emerged as a candidate that mediates synaptic modification. In addition to its acute effects (Lohof et al., 1993; Kang and Schuman, 1995; Figurov et al., 1996), BDNF exerts its long-term effects on synaptic transmission (Rutherford et al., 1998), synaptic refinement (Cabelli et al., 1995; Horch et al. 1999), and neurite growth (Cohen-Cory and Fraser, 1995; McAllister et al., 1995, 1997; Song et al., 1997; Gallo and Letourneau, 1998) during development. Little is known, however, about the pathogenetic role of BDNF. We have shown that BDNF serves as an etiologic factor for epilepsy-related reactive sprouting, suggesting its role for limbic epileptogenesis.

\section{BDNF is causal in inducing MF sprouting}

Seizure-induced upregulation of BDNF mRNA (Isackson et al., 1991; Gall, 1993) and protein (Nawa et al., 1995; Elmer et al., 1998; Rudge et al., 1998; Vezzani et al., 1999) in the hippocampus is a common phenomenon across various experimental models of epilepsy. Nonetheless, evidence for a specific contribution of BDNF to MF sprouting is still controversial. Vaidya et al. (1999) showed that MF sprouting is diminished in mice heterozygous for a deletion of the BDNF gene, in which animals the BDNF expression level is substantially reduced. However, Kokaia et al. (1995) reported an increased degree of MF sprouting in the same mutant mice. Scharfman et al. (2002) indicated that infusion of BDNF into the hippocampus induces MF sprouting. In contrast, Vaidya et al. (1999) demonstrated that the BDNF infusion has no effect, and Qiao et al. (2001) showed that transgenic mice overexpressing BDNF display no MF sprouting.

These complicated, apparently contradictory, observations could be attributable to different experimental procedures and/or individual difference among animals. We consider, however, that MF sprouting is essentially a local phenomenon that is subject to systemic and extrahippocampal influences. In our simplified experimental system, indeed, local BDNF action in the hilus triggered MF sprouting, but global application of BDNF masked this effect. This may explain the inconsistency in the literature.

Based on our observations, it is no doubt that BDNF plays a causal role in MF sprouting. We do not believe, however, that reactive sprouting is always attributable to BDNF action. For example, in response to deafferentation of the perforant path, the MFs display a morphological change that resembles epilepsyrelated sprouting (Laurberg and Zimmer 1981; Frotscher and Zimmer 1983). This form of sprouting is likely to result from a transient downregulation in Sema3A that is provided from entorhinal stellate cells (Holtmaat et al., 2003), one of chemorepellents against MF growth (Chen et al., 2000). Indeed, deafferentationinduced sprouting is unaffected in BDNF-deficient mice (Bender et al., 1998).

\section{Activity-dependent synaptic reorganization and BDNF}

The fact that hyperactivity-induced MF sprouting was inhibited by function-blocking anti-BDNF antibody indicates a requirement of the extracellular action of BDNF. Activity-dependent release of BDNF has been well documented in various experimental systems (Goodman et al., 1996; Balkowiec and Katz, 2000; Hartmann et al., 2001; Kohara et al., 2001; Gärtner and Staiger, 
2002). Considering that hyperactivity induced a selective increase in BDNF immunoreactivity in the MF pathway, it is plausible that BDNF is extracellularly released from MF terminals, although evidence that the MFs actually release BDNF is still rudimentary (Katoh-Semba et al., 1999).

BDNF beads were effective only when placed on the hilus, and thus, the locus of BDNF action seems to be within the dentate hilus. The effective range of BDNF diffusion from a gel bead is probably up to $100 \mu \mathrm{m}$ in cultured tissues because the beads were ineffective if put on the molecular layer, a region only $<100 \mu \mathrm{m}$ apart from the hilus. Thus, BDNF does not serve as a chemoattractant to guide the MFs toward the molecular layer (Song et al., 1997) but rather works as a factor that triggers axon branching (Cohen-Cory and Fraser, 1995). This idea is supported by our observations that in isolated granule cells, application of BDNF led to an increase in axonal protrusions.

We consider that BDNF-induced branching-out of MF collaterals is the "determining" step to epileptogenic reorganization of the dentate circuits (Koyama and Ikegaya, 2004). In this respect, we hypothesize as follows: the MFs form a "cohesive" bundle, to which the MFs can adhere. The bundle can serve as a contactdependent axon guidance system to help MFs to arise from newly born granule cells to find their correct trajectories (Kim et al., 2004; Koyama et al., 2004). However, when aberrant axonal collaterals sprout out in the hilus, they also would follow the bundle in the midway of the MF tract, in which case, by chance, half of them are oriented in the correct direction toward CA3, and the remaining in the wrong direction toward molecular layer. Therefore, once MF collaterals sprout, they would inevitably reorganize the dentate network. This process does not require neuronal activity, consistent with our observations that activity blockade did not prevent BDNF-induced MF sprouting.

It is intriguing that BDNF beads in the stratum lucidum did not initiate MF sprouting, regardless of the fact that like the hilus, this substratum also constitutes a part of the MF trajectory. The MF axons thus appeared to be compartmentalized across their length; the hilar and lucidum segments show differential susceptibility to BDNF. BDNF is suggested to be incorporated with TrkB and transported retrogradely along an axon as a complex with TrkB and initiate its signal (Watson et al., 1999), but our study indicates that BDNF transported from the stratum lucidum to the hilus, if any, does not induce MF sprouting, suggesting that the axon segmentation of MF is robust and enables BDNF to work locally.

\section{BDNF induces axon branching}

In isolated granule cell cultures, BDNF increased the number of axonal protrusions, consistent with previous studies showing that BDNF induced increases in axonal length, number, and branching in primary cultures (Patel and McNamara, 1995) and organotypic cultures (Lowenstein and Arsenault, 1996a,b; Danzer et al., 2002). None of these studies, however, determined whether the effect of BDNF is direct or indirect. Our results of dnTrkB transfection now provide evidence that BDNF acts directly on granule cells to induce axon branching. Considering that in ex vivo cultures, BDNF had no apparent effect unless
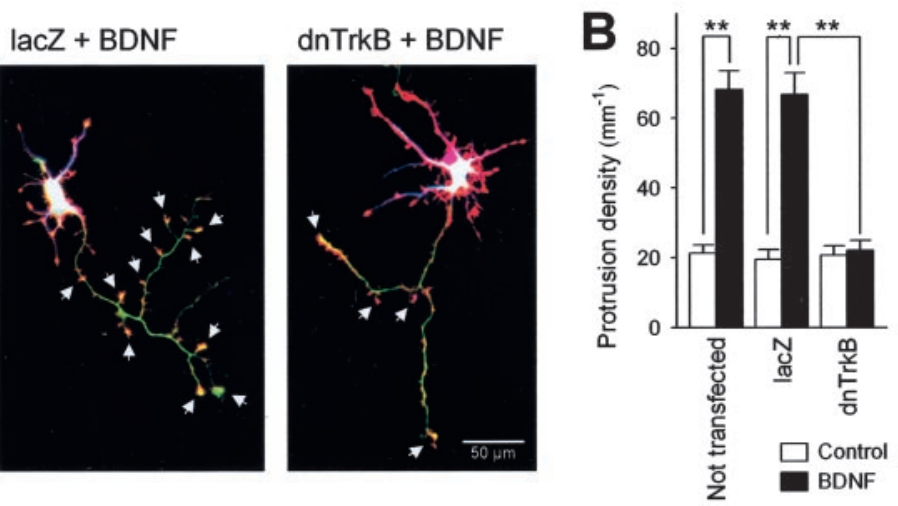

Figure 8. BDNF directly acts on granule cells to induce axonal sprouting. $A$, Confocal images of lacZ- or dominant-negative TrkB transfection, cultures were exposed to $10 \mathrm{ng} / \mathrm{ml}$ BDNF for $24 \mathrm{hr}$ and stained with rhodamine phalloidin (red) and anti-MAP-2 ue). Transfection with lacZ was used as a negative control for gene expression. B, Quantitative analysis of axonal protrusions. Data of "not transfected" were derived from neighboring untransfected neurons in the same batches. ${ }^{* *} p<0.01$; Tukey's test after ANOVA. Data are means \pm SEM of 116-254 axon segments in eight different series of cultures.

locally applied to the hilus, the most probable primary target of BDNF action is the axons of granule cells.

Cytoskeletal proteins, including actin microfilaments, microtubules, and neurofilaments, have been shown to be intracellular downstream targets of neurotrophins and to mediate the morphological changes induced by neurotrophins. For example, in PC12 cells treated with nerve growth factor, neurite outgrowth depends on the expression of tau (Brandt et al., 1995) and MAP1B (Brugg et al., 1993). In human B lymphocytes, nerve growth factor induces polymerization of actin microfilaments by increasing tyrosine phosphorylation of paxillin, a cytoskeletal associated protein (Melamed et al., 1995). In the case of BDNF, it induces the expression of neurofilaments in hippocampal cultures (Ip et al., 1993). In Xenopus embryonic neurons, BDNFinduced collateral membrane protrusions depend on actin and microtubule dynamics (Gibney and Zhang, 2003). Similar mechanisms may operate during MF reorganization. Further investigations are necessary to clarify the intracellular mechanisms underlying BDNF-TrkB signaling-induced MF reorganizations. At this moment, however, we have not succeeded in demonstrating the contribution of cytoskeletons to MF sprouting, because the survival of granule cells themselves is highly vulnerable to disruptions of cytoskeleton dynamics (Kim et al., 2002).

We notice that BDNF has an indirect effect as well. In ex vivo cultures, local activation of BDNF-TrkB signaling in the hilus induces MF sprouting, but its global activation failed to produce the same structural alterations. The results imply the existence of preventive mechanisms that can counteract the "pro-sprouting" effect of hilar BDNF. The "anti-sprouting" mechanisms are unlikely mediated by granule cells, because bath application of BDNF to isolated granule cells was still effective. Surrounding cells such as glia and other types of neurons present in organotypic cultures may protect MFs against the pathogenic reorganization. It may be noteworthy that in general, inhibitory interneurons are more preferentially activated by BDNF than excitatory principal neurons (Marty et al., 2000; Yamada et al., 2002). As a whole, therefore, the actions of BDNF may be complicated and multifaceted, as seen in the past literature.

Finally, our interpretation of the data obtained here could be extrapolated on the real events happening during seizure with caution, but the final conclusion on a role of BDNF in epileptic axonal remodeling still requires experiments with living model 
animals and human patients. To this goal, we hope that this work provides a useful framework for further investigations.

\section{References}

Amaral DG, Witter MP (1995) Hippocampal formation. In: The rat nervous system, Ed 2 (Paxinos C, ed), pp 443-493. New York: Academic.

Ayala GF, Dichter M, Gumnit RJ, Matsumoto H, Spencer WA (1973) Genesis of epileptic interictal spikes. New knowledge of cortical feedback systems suggests a neurophysiological explanation of brief paroxysms. Brain Res 52:1-17.

Baba A, Yasui T, Fujisawa S, Yamada RX, Yamada MK, Nishiyama N, Matsuki N, Ikegaya Y (2003) Activity-evoked capacitative $\mathrm{Ca}^{2+}$ entry: implications in synaptic plasticity. J Neurosci 23:7737-7741.

Babb TL, Kupfer WR, Pretorius JK, Crandall PH, Levesque MF (1991) Synaptic reorganization by mossy fibers in human epileptic fascia dentata. Neuroscience 42:351-363.

Balkowiec A, Katz DM (2000) Activity-dependent release of endogenous brain-derived neurotrophic factor from primary sensory neurons detected by ELISA in situ. J Neurosci 20:7417-7423.

Bender R, Heimrich B, Meyer M, Frotscher M (1998) Hippocampal mossy fiber sprouting is not impaired in brain-derived neurotrophic factordeficient mice. Exp Brain Res 120:399-402.

Bengzon J, Kokaia Z, Ernfors P, Kokaia M, Leanza G, Nilsson OG, Persson H, Lindvall O (1993) Regulation of neurotrophin and trkA, trkB and trkC tyrosine kinase receptor messenger RNA expression in kindling. Neuroscience 53:433-446.

Binder DK, Croll SD, Gall CM, Scharfman HE (2001) BDNF and epilepsy: too much of a good thing? Trends Neurosci 24:47-53.

Brandt R, Leger J, Lee G (1995) Interaction of tau with the neural plasma membrane mediated by tau's amino-terminal projection domain. J Cell Biol 131:1327-1340.

Brugg B, Reddy D, Matus A (1993) Attenuation of microtubule-associated protein $1 \mathrm{~B}$ expression by antisense oligodeoxynucleotides inhibits initiation of neurite outgrowth. Neuroscience 52:489-496.

Buckmaster PS, Zhang GF, Yamawaki R (2002) Axon sprouting in a model of temporal lobe epilepsy creates a predominantly excitatory feedback circuit. J Neurosci 22:6650-6658.

Cabelli RJ, Hohn A, Shatz CJ (1995) Inhibition of ocular dominance column formation by infusion of NT-4/5 or BDNF. Science 267:1662-1666.

Cavazos JE, Zhang P, Qazi R, Sutula TP (2003) Ultrastructural features of sprouted mossy fiber synapses in kindled and kainic acid-treated rats. J Comp Neurol 458:272-292.

Chen H, Bagri A, Zupicich JA, Zou Y, Stoeckli E, Pleasure SJ, Lowenstein DH, Skarnes WC, Chedotal A, Tessier-Lavigne M (2000) Neuropilin-2 regulates the development of selective cranial and sensory nerves and hippocampal mossy fiber projections. Neuron 25:43-56.

Cohen-Cory S, Fraser SE (1995) Effects of brain-derived neurotrophic factor on optic axon branching and remodelling in vivo. Nature 378:192-196.

Cronin J, Dudek FE (1988) Chronic seizures and collateral sprouting of dentate mossy fibers after kainic acid treatment in rats. Brain Res 474:181-184.

Danscher G, Zimmer J (1978) An improved Timm sulphide silver method for light and electron microscopic localization of heavy metals in biological tissues. Histochemistry 55:27-40.

Danzer SC, Crooks KR, Lo DC, McNamara JO (2002) Increased expression of brain-derived neurotrophic factor induces formation of basal dendrites and axonal branching in dentate granule cells in hippocampal explant cultures. J Neurosci 22:9754-9763.

de Lanerolle NC, Kim JH, Robbins RJ, Spencer DD (1989) Hippocampal interneuron loss and plasticity in human temporal lobe epilepsy. Brain Res 495:387-395.

Dichter MA, Ayala GF (1987) Cellular mechanisms of epilepsy: a status report. Science 237:157-164.

Elmer E, Kokaia Z, Kokaia M, Carnahan J, Nawa H, Lindvall O (1998) Dynamic changes of brain-derived neurotrophic factor protein levels in the rat forebrain after single and recurring kindling-induced seizures. Neuroscience 83:351-362.

Feng L, Molnar P, Nadler JV (2003) Short-term frequency-dependent plasticity at recurrent mossy fiber synapses of the epileptic brain. J Neurosci 23:5381-5390.

Figurov A, Pozzo-Miller LD, Olafsson P, Wang T, Lu B (1996) Regulation of synaptic responses to high-frequency stimulation and LTP by neurotrophins in the hippocampus. Nature 381:706-709.
Frotscher M, Zimmer J (1983) Lesion-induced mossy fibers to the molecular layer of the rat fascia dentata: identification of postsynaptic granule cells by the Golgi-EM technique. J Comp Neurol 215:299-311.

Gall CM (1993) Seizure-induced changes in neurotrophin expression: implications for epilepsy. Exp Neurol 124:150-166.

Gallo G, Letourneau PC (1998) Localized sources of neurotrophins initiate axon collateral sprouting. J Neurosci 18:5403-5414.

Gärtner A, Staiger V (2002) Neurotrophin secretion from hippocampal neurons evoked by long-term-potentiation-inducing electrical stimulation patterns. Proc Natl Acad Sci USA 99:6386-6391.

Ghosh A, Carnahan J, Greenberg ME (1994) Requirement for BDNF in activity-dependent survival of cortical neurons. Science 263:1618-1623.

Gibney J, Zheng JQ (2003) Cytoskeletal dynamics underlying collateral membrane protrusions induced by neurotrophins in cultured Xenopus embryonic neurons. J Neurobiol 54:393-405.

Goodman LJ, Valverde J, Lim F, Geschwind MD, Federoff HJ, Geller AI, Hefti F (1996) Regulated release and polarized localization of brain-derived neurotrophic factor in hippocampal neurons. Mol Cell Neurosci 7:222-238.

Hartmann M, Heumann R, Lessmann V (2001) Synaptic secretion of BDNF after high-frequency stimulation of glutamatergic synapses. EMBO 20:5887-5897.

He XP, Minichiello L, Klein R, McNamara JO (2002) Immunohistochemical evidence of seizure-induced activation of trkB receptors in the mossy fiber pathway of adult mouse hippocampus. J Neurosci 22:7502-7508.

Holtmaat AJ, Gorter JA, De Wit J, Tolner EA, Spijker S, Giger RJ, Lopes da Silva FH, Verhaagen J (2003) Transient downregulation of Sema3A mRNA in a rat model for temporal lobe epilepsy. A novel molecular event potentially contributing to mossy fiber sprouting. Exp Neurol 182:142-150.

Horch HW, Kruttgen A, Portbury SD, Katz LC (1999) Destabilization of cortical dendrites and spines by BDNF. Neuron 23:353-364.

Ikegaya Y (1999) Abnormal targeting of developing hippocampal mossy fibers after epileptiform activities via L-type $\mathrm{Ca}^{2+}$ channel activation in vitro. J Neurosci 19:802-812.

Ikegaya Y, Ikeda Y, Saito H, Nishiyama N (1998) Suppression of synaptogenesis by epileptiform discharges in hippocampal slice culture. Biol Pharmacol Bull 21:231-234.

Ip NY, Li Y, Yancopoulos GD, Lindsay RM (1993) Cultured hippocampal neurons show responses to BDNF, NT-3, and NT-4, but not NGF. J Neurosci 13:3394-3405.

Isackson PJ, Huntsman MM, Murray KD, Gall CM (1991) BDNF mRNA expression is increased in adult rat forebrain after limbic seizures: temporal patterns of induction distinct from NGF. Neuron 6:937-948.

Kang H, Schuman EM (1995) Long-lasting neurotrophin-induced enhancement of synaptic transmission in the adult hippocampus. Science 267:1658-1662.

Katoh-Semba R, Takeuchi IK, Inaguma Y, Ito H, Kato K (1999) Brainderived neurotrophic factor, nerve growth and neurotrophin-3 selected regions of the rat brain following kainic acid-induced seizure activity. Neurosci Res 35:19-29.

Katoh-Semba R, Takeuchi IK, Inaguma Y, Ichisaka S, Hata Y, Tsumoto T, Iwai M, Mikoshiba K, Kato K (2001) Induction of brain-derived neurotrophic factor by convulsant drugs in the rat brain: involvement of regionspecific voltage-dependent calcium channels. J Neurochem 77:71-83.

Katoh-Semba R, Asano T, Ueda H, Morishita R, Takeuchi IK, Inaguma Y, Kato K (2002) Riluzole enhances expression of brain-derived neurotrophic factor with consequent proliferation of granule precursor cells in the rat hippocampus. FASEB J 16:1328-1330.

Kim JA, Mitsukawa K, Yamada MK, Nishiyama N, Matsuki N, Ikegaya Y (2002) Cytoskeleton disruption causes apoptotic degeneration of dentate granule cells in hippocampal slice cultures. Neuropharmacology 42:1109-1118.

Kim J-A, Koyama R, Yamada RX, Yamada MK, Nishiyama N, Matsuki N, Ikegaya Y (2004) Environmental control of the survival and differentiation of dentate granule neurons. Cereb Cortex, in press.

Kohara K, Kitamura A, Morishima M, Tsumoto T (2001) Activitydependent transfer of brain-derived neurotrophic factor to postsynaptic neurons. Science 291:2419-2423.

Kokaia M, Ernfors P, Kokaia Z, Elmer E, Jaenisch R, Lindvall O (1995) Suppressed epileptogenesis in BDNF mutant mice. Exp Neurol 133:215-224.

Koyama R, Ikegaya Y (2004) Mossy fiber sprouting as a potential therapeutic target for epilepsy. Curr Neurovasc Res 1:3-10.

Koyama R, Yamada MK, Nishiyama N, Matsuki N, Ikegaya Y (2004) Devel- 
opmental switch in axon guidance modes of hippocampal mossy fibers in vitro. Dev Biol 267:29-42.

Laurberg S, Zimmer J (1981) Lesion-induced sprouting of hippocampal mossy fiber collaterals to the fascia dentata in developing and adult rats. J Comp Neurol 200:433-459.

LeMasson G, Marder E, Abbott LF (1993) Activity-dependent regulation of conductances in model neurons. Science 259:1915-1917.

Lohof AM, Ip NY, Poo MM (1993) Potentiation of developing neuromuscular synapses by the neurotrophins NT-3 and BDNF. Nature 363:350-353.

Lowenstein DH, Arsenault L (1996a) Dentate granule cell layer collagen explant cultures: spontaneous axonal growth and induction by brainderived neurotrophic factor or basic fibroblast growth factor. Neuroscience 74:1197-1208.

Lowenstein DH, Arsenault L (1996b) The effects of growth factors on the survival and differentiation of cultured dentate gyrus neurons. J Neurosci 16:1759-1769.

Lynch M, Sutula T (2000) Recurrent excitatory connectivity in the dentate gyrus of kindled and kainic acid-treated rats. J Neurophysiol 83:693-704.

McAllister AK, Lo DC, Katz LC (1995) Neurotrophins regulate dendritic growth in developing visual cortex. Neuron 15:791-803.

Marty S, Wehrle R, Sotelo C (2000) Neuronal activity and brain-derived neurotrophic factor regulate the density of inhibitory synapses in organotypic slice cultures of postnatal hippocampus. J Neurosci 20:8087-8095.

McAllister AK, Katz LC, Lo DC (1997) Opposing roles for endogenous BDNF and NT-3 in regulating cortical dendritic growth. Neuron 18:767-778.

Melamed I, Turner CE, Aktories K, Kaplan DR, Gelfand EW (1995) Nerve growth factor triggers microfilament assembly and paxillin phosphorylation in human B lymphocytes. J Exp Med 181:1071-1079.

Mizuhashi S, Nishiyama N, Matsuki N, Ikegaya Y (2001) Cyclic nucleotidemediated regulation of hippocampal mossy fiber development: a targetspecific guidance. J Neurosci 21:6181-6194.

Molnar P, Nadler JV (1999) Mossy fiber-granule cell synapses in the normal and epileptic rat dentate gyrus studied with minimal laser photostimulation. J Neurophysiol 82:1883-1894.

Nawa H, Carnahan J, Gall C (1995) BDNF protein measured by a novel enzyme immunoassay in normal brain and after seizure: partial disagreement with mRNA levels. Eur J Neurosci 7:1527-1535.

Ohba S, Ikeda T, Ikegaya Y, Nishiyama N, Matsuki N, Yamada MK (2004) BDNF locally potentiates GABAergic presynaptic machineries: targetselective circuit inhibition. Cereb Cortex, in press.

Okazaki MM, Evenson DA, Nadler JV (1995) Hippocampal mossy fiber sprouting and synapse formation after status epilepticus in rats: visualization after retrograde transport of biocytin. J Comp Neurol 352:515-534.

Patel MN, McNamara JO (1995) Selective enhancement of axonal branching of cultured dentate gyrus neurons by neurotrophic factors. Neuroscience 69:763-770.

Poulsen FR, Jahnsen H, Blaabjerg M, Zimmer J (2002) Pilocarpine-induced seizure-like activity with increased BNDF and neuropeptide $\mathrm{Y}$ expression in organotypic hippocampal slice cultures. Brain Res 950:103-118.

Qiao X, Suri C, Knusel B, Noebels JL (2001) Absence of hippocampal mossy fiber sprouting in transgenic mice overexpressing brain-derived neurotrophic factor. J Neurosci Res 64:268-276.

Rudge JS, Mather PE, Pasnikowski EM, Cai N, Corcoran T, Acheson A, Anderson K, Lindsay RM, Wiegand SJ (1998) Endogenous BDNF protein is increased in adult rat hippocampus after a kainic acid induced excitotoxic insult but exogenous BDNF is not neuroprotective. Exp Neurol 149:398-410.

Rutherford LC, Nelson SB, Turrigiano GG (1998) BDNF has opposite effects on the quantal amplitude of pyramidal neuron and interneuron excitatory synapses. Neuron 21:521-530.

Sano K, Nanba H, Tabuchi A, Tsuchiya T, Tsuda M (1996) BDNF gene can Be activated by $\mathrm{Ca}^{2+}$ signals without involvement of de novo AP-1 synthesis. Biochem Biophys Res Commun 229:788-793.

Scharfman HE, Goodman JH, Sollas AL, Croll SD (2002) Spontaneous limbic seizures after intrahippocampal infusion of brain-derived neurotrophic factor. Exp Neurol 174:201-214.

Shieh PB, Hu SC, Bobb K, Timmusk T, Ghosh A (1998) Identification of a signaling pathway involved in calcium regulation of BDNF expression. Neuron 20:727-740.
Shimada A, Mason CA, Morrison ME (1998) TrkB signaling modulates spine density and morphology independent of dendrite structure in cultured neonatal Purkinje cells. J Neurosci 18:8559-8570.

Sloviter RS, Nilaver G (1987) Immunocytochemical localization of GABA-, cholecystokinin-, vasoactive intestinal polypeptide-, and somatostatinlike immunoreactivity in the area dentata and hippocampus of the rat. J Comp Neurol 256:42-60.

Sloviter RS, Dichter MA, Rachinsky TL, Dean E, Goodman JH, Sollas AL, Martin DL (1996) Basal expression and induction of glutamate decarboxylase and GABA in excitatory granule cells of the rat and monkey hippocampal dentate gyrus. J Comp Neurol 373:593-618.

Song HJ, Ming GL, Poo MM (1997) cAMP-induced switching in turning direction of nerve growth cones. Nature 388:275-279.

Stemmler M, Koch C (1999) How voltage-dependent conductances can adapt to maximize the information encoded by neuronal firing rate. Nat Neurosci 2:521-527.

Steriade M (2003) Neuronal substrates of sleep and epilepsy. Cambridge, UK: Cambridge UP.

Stoppini L, Buchs PA, Muller D (1991) A simple method for organotypic cultures of nervous tissue. J Neurosci Methods 37:173-182.

Sutula T, He XX, Cavazos J, Scott G (1988) Synaptic reorganization in the hippocampus induced by abnormal functional activity. Science 239:1147-1150.

Tabuchi A, Nakaoka R, Amano K, Yukimine M, Andoh T, Kuraishi Y, Tsuda M (2000) Differential activation of brain-derived neurotrophic factor gene promoters I and III by $\mathrm{Ca}^{2+}$ signals evoked via L-type voltagedependent and N-methyl-d-aspartate receptor $\mathrm{Ca}^{2+}$ channels. J Biol Chem 275:17269-17275.

Tanaka T, Saito H, Matsuki N (1997) Inhibition of GABAA synaptic responses by brain-derived neurotrophic factor (BDNF) in rat hippocampus. J Neurosci 17:2959-2966.

Tao X, Finkbeiner S, Arnold DB, Shaywitz AJ, Greenberg ME (1998) $\mathrm{Ca}^{2+}$ influx regulates BDNF transcription by a CREB family transcription factor-dependent mechanism. Neuron 20:709-726.

Turrigiano G, Abbott LF, Marder E (1994) Activity-dependent changes in the intrinsic properties of cultured neurons. Science 264:974-977.

Turrigiano GG, Leslie KR, Desai NS, Rutherford LC, Nelson SB (1998) Activity-dependent scaling of quantal amplitude in neocortical neurons. Nature 391:892-896.

Tyler WJ, Pozzo-Miller LD (2001) BDNF enhances quantal neurotransmitter release and increases the number of docked vesicles at the active zones of hippocampal excitatory synapses. J Neurosci 21:4249-4258.

Ueno S, Tsukamoto M, Hirano T, Kikuchi K, Yamada MK, Nishiyama N, Nagano T, Matsuki N, Ikegaya Y (2002) Mossy fiber $\mathrm{Zn}^{2+}$ spillover modulates heterosynaptic $N$-methyl-D-aspartate receptor activity in hippocampal CA3 circuits. J Cell Biol 158:215-220.

Vaidya VA, Siuciak JA, Du F, Duman RS (1999) Hippocampal mossy fiber sprouting induced by chronic electroconvulsive seizures. Neuroscience 89:157-166.

Vezzani A, Ravizza T, Moneta D, Conti M, Borroni A, Rizzi M, Samanin R, Maj R (1999) Brain-derived neurotrophic factor immunoreactivity in the limbic system of rats after acute seizures and during spontaneous convulsions: temporal evolution of changes as compared to neuropeptide Y. Neuroscience 90:1445-1461.

Watson FL, Heerssen HM, Moheban DB, Lin MZ, Sauvageot CM, Bhattacharyya A, Pomeroy SL, Segal RA (1999) Rapid nuclear responses to target-derived neurotrophins require retrograde transport of ligandreceptor complex. J Neurosci 19:7889-7900.

Wuarin JP, Dudek FE (1996) Electrographic seizures and new recurrent excitatory circuits in the dentate gyrus of hippocampal slices from kainatetreated epileptic rats. J Neurosci 16:4438-4448.

Yamada MK, Nakanishi K, Ohba S, Nakamura T, Ikegaya Y, Nishiyama N, Matsuki N (2002) Brain-derived neurotrophic factor promotes the maturation of GABAergic mechanisms in cultured hippocampal neurons. J Neurosci 22:7580-7585.

Yamamoto N, Kurotani T, Toyama K (1989) Neural connections between the lateral geniculate nucleus and visual cortex in vitro. Science 245:192-194. 